\title{
TTR
}

Traduction, terminologie, re?daction

\section{Mossop, Brian. Revising and Editing for Translators, Manchester, UK, St. Jerome Publishing, 2001, 177 p.}

\section{Alain René}

Volume 15, numéro 1, 1er semestre 2002

La traduction au Canada : Tendances et traditions

Translation in Canada : Trends and Traditions

URI : https://id.erudit.org/iderudit/006808ar

DOI : https://doi.org/10.7202/006808ar

Aller au sommaire du numéro

\section{Éditeur(s)}

Association canadienne de traductologie

ISSN

0835-8443 (imprimé)

1708-2188 (numérique)

Découvrir la revue

Citer ce compte rendu

René, A. (2002). Compte rendu de [Mossop, Brian. Revising and Editing for Translators, Manchester, UK, St. Jerome Publishing, 2001, 177 p.] TTR, 15(1),

241-243. https://doi.org/10.7202/006808ar d'utilisation que vous pouvez consulter en ligne.

https://apropos.erudit.org/fr/usagers/politique-dutilisation/ 


\section{COMPTES RENDUS}

\section{Mossop, Brian. Revising and Editing for Translators, Manchester, UK, St. Jerome Publishing, 2001, 177 p.}

Le traducteur qui commence à faire de la révision risque de se trouver fort démuni devant le peu de ressources qui s'offrent à lui pour le guider dans ses nouvelles fonctions. Brian Mossop nous propose un nouvel ouvrage, Revising and Editing for Translators, dans lequel il aborde, de façon pratique et concrète, les multiples aspects du métier de réviseur ou de rédacteur-réviseur.

D'emblée, l'auteur précise que son ouvrage s'adresse à deux types de lecteurs : l'étudiant en traduction qui apprend à corriger des textes écrits par d'autres, et le traducteur de métier qui désire perfectionner ses techniques d'auto-révision ou veut apprendre à réviser le travail d'autres traducteurs. En fait, les professeurs y trouveront également un guide qui ne manquera pas de les intéresser, puisque l'auteur a pris soin d'intégrer dans son livre une multitude de conseils didactiques, de suggestions de lecture et d'exercices.

Mais, revenons au titre : Revising and Editing for Translators. Ces deux termes, que l'on traduit souvent en français par le seul mot révision, englobent un large éventail de notions et de tâches que l'auteur décrit en détail dans les 14 chapitres de son ouvrage. Il précise d'ailleurs que, bien que le terme Editing désigne à la fois les tâches portant précisément sur la correction de textes et celles qui concernent en général l'édition d'un document (recherche de rédacteurs, gestion du contenu, conception de la mise en page, etc.), il se concentre dans son ouvrage sur les activités qui touchent la révision proprement dite d'un texte.

Puisant dans sa vaste expérience du métier, l'auteur énonce les raisons pour lesquelles un texte doit faire l'objet d'une révision, ou au moins d'une auto-révision. Il explique, toujours d'un point de vue éminemment pratique, que la révision a ses limites, qu'il est parfois plus rentable de refaire un texte que de tenter de le réviser. Il énonce, plus loin, les différents types de révision : la préparation de la copie 
(copyediting) - conventions typographiques, orthographe, ponctuation, grammaire, syntaxe et caractère idiomatique; la révision du style (stylistic editing) — adaptation au lecteur et fluidité du texte; la révision de la structure (structural editing) _ organisation matérielle du texte, division en paragraphes, rubriques; la révision du contenu (content editing) - contenu en général, erreurs de logique ou de nature mathématique; contrôle de l'uniformité (checking for consistency).

Le réviseur d'aujourd'hui dispose de tout un arsenal d'outils informatiques qui peuvent lui simplifier la tâche, mais qui comportent aussi leurs limites. À cette nouvelle réalité, l'auteur consacre tout un chapitre, dans lequel il se pose la question : faut-il travailler sur papier ou à l'écran? Il décrit au passage les différentes fonctions des logiciels de traitement de texte utiles au réviseur, comme le correcteur orthographique et grammatical, les fonctions Rechercher et remplacer, Suivi des modifications, ainsi que Comparer des documents. Il soulèvera plus loin, d'ailleurs, la question de la révision de traductions machine.

Il aborde en outre les différentes facettes du travail d'un réviseur dans un service de traduction. Là encore, l'auteur démontre sa connaissance intime du métier et sensibilise le lecteur à la nécessité de tenir compte des intérêts de bien des personnes : l'auteur du texte, le client, le lecteur et le traducteur. Il insiste aussi sur le juste et difficile équilibre à trouver entre la qualité du produit fini et le temps à y consacrer. Sur ce point, aucun doute : la qualité prend du temps (et le temps, c'est de l'argent). Il importe de bien choisir le procédé de contrôle de la qualité qui convient : révision en bonne et due forme, contrôle par échantillonnage, simple relecture du texte d'arrivée, etc.

Quel que soit le procédé qu'emploie le réviseur pour assurer la qualité du produit, il doit respecter un certain nombre de paramètres, que l'auteur énonce et explique en détail : la fidélité au texte de départ, bien sûr, et d'autres, comme l'intégralité du message, la cohérence, la fluidité, l'adaptation au destinataire, la disposition, et ainsi de suite. Dans quelle mesure, aussi, faut-il réviser? À quoi servira le texte? Par qui et combien de fois sera-t-il lu? Autant de questions que le réviseur doit se poser pour bien doser son effort, qu'il s'agisse de la révision de son propre travail ou du travail d'une autre personne.

Un index, une bibliographie et cinq annexes viennent compléter l'ouvrage. L'auteur propose notamment en annexe un 
résumé des principes de la révision, un glossaire, ainsi qu'une méthode d'évaluation de la qualité.

L'ouvrage de M. Mossop ajoute une pièce très utile à la trousse de quiconque est appelé à faire de la révision de textes. Encore une fois, les lecteurs sauront certainement apprécier le côté très pratique de ce document, qui de toute évidence est le fruit d'une longue expérience et d'une réflexion profonde sur la pratique de la révision.

\section{Alain René \\ Université d'Ottawa}

\section{Christina Schäffner (ed.). The Role of Discourse Analysis for Translation and in Translator Training, Clevedon, Buffalo, Toronto, Sydney, Multilingual Matters Ltd., 2002, 95 p.}

This book first appeared as volume 7, number 3 of the journal Current Issues in Language and Society. As with several other issues of this journal, there was judged to be sufficient interest for a separate publication in book form. The format of the contributions in the book therefore represent a rather special process by which the journal elicits submissions. A specialist in a field relevant to translation is invited to deliver a paper at Aston University to an audience that is also knowledgeable in the field. The ensuing debate is transcribed and published with the paper. In this particular case the speaker was Anna Trosberg of the Department of English in the Aarhus School of Business in Denmark. In addition to the debate itself there are responses to the paper prepared by Beverly Adab, Rodica Dimitriu, Carmen Millán-Varela, Peter Newmark, and Palma Zlateva, and Trosberg's concluding remarks.

The presentation plus reaction can lead to an uneven sense of direction, and both the editorial at the beginning and the sections of commentary on the paper make it clear that there was disagreement as to the applicability of the kind of analysis Trosberg was exposing. The title of Trosberg's presentation is Discourse Analysis as Part of Translator Training. In the abstract she clearly limits the scope of her intention by describing the class in which she uses this approach. Her students are taking an optional course in translation, and their interest is in "in-depth textual analysis that is translation oriented" (p. 9). 